\title{
Phylogeny of Myzostomida (Annelida) and their relationships with echinoderm hosts
}

\author{
Mindi M Summers ${ }^{*}$ and Greg W Rouse*
}

\begin{abstract}
Background: Myzostomids are marine annelids, nearly all of which live symbiotically on or inside echinoderms, chiefly crinoids, and to a lesser extent asteroids and ophiuroids. These symbionts possess a variety of adult body plans and lifestyles. Most described species live freely on the exterior of their hosts as adults (though starting life on the host inside cysts), while other taxa permanently reside in galls, cysts, or within the host's mouth, digestive system, coelom, or gonads. Myzostomid lifestyles range from stealing incoming food from the host's food grooves to consuming the host's tissue directly. Previous molecular studies of myzostomids have had limited sampling with respect to assessing the evolutionary relationships within the group; therefore molecular data from 75 myzostomid taxa were analyzed using maximum likelihood and maximum parsimony methods. To compare relationships of myzostomids with their hosts, a phylogeny was inferred for 53 hosts and a tanglegram constructed with 88 associations.

Results: Gall- and some cyst-dwellers were recovered as a clade, while cyst-to-free-living forms were found as a grade including two clades of internal host-eaters (one infecting crinoids and the other asteroids and ophiuroids), mouth/digestive system inhabitants, and other cyst-dwellers. Clades of myzostomids were recovered that associated with asteroids, ophiuroids, and stalked or feather star crinoids. Co-phylogenetic analyses rejected a null-hypothesis of random associations at the global level, but not for individual associations. Event-based analyses relied most upon host-switching and duplication events to reconcile the association history.

Conclusion: Hypotheses were revised concerning the systematics and evolution of Myzostomida, as well their relationships to their hosts. We found two or three transitions between food-stealing and host-eating. Taxa that dwell within the mouth or digestive system and some cyst forms are arguably derived from cyst-to-free-living ancestors - possibly the result of a free-living form moving to the mouth and paedomorphic retention of the juvenile cyst. Phylogenetic conservatism in host use was observed among related myzostomid taxa. This finding suggests that myzostomids (which have a free-living planktonic stage) are limited to one or a few closely related hosts, despite most hosts co-occurring on the same reefs, many within physical contact of each other.
\end{abstract}

Keywords: Co-phylogeny, Parasitism, Symbiosis, Taxonomy, Systematics, Asteromyzostomum, Contramyzostoma, Eenymeenymyzostoma, Myzostoma, Protomyzostomum

\section{Background}

Myzostomida Graff, 1877 is a clade of marine annelid worms with around 150 described species. Most spend their adult lives living on or inside crinoid echinoderms; about a dozen species are associated with ophiuroids and asteroids; two occur on black coral (Antipatharia) $[1,2]$; and one has been recorded from a sponge [3]. Myzostomids occur in shallow subtidal to abyssal depths

\footnotetext{
*Correspondence: msummers@ucsd.edu; grouse@ucsd.edu

Scripps Institution of Oceanography, UCSD, 9500 Gilman Drive, La Jolla, CA 92093, USA
}

throughout all of the world's oceans, but are mainly found in shallow-water tropical reefs where crinoid diversity is greatest [4,5]. Myzostomids possess a variety of body plans and lifestyles in which they steal food from or directly consume the host (Figure 1). Those that live on the surface of the animal are mainly disk-shaped or elongated; they use their chaetae to hold onto the host while inserting their proboscis into the host's food groove to steal food $[4,6]$. These external types may "mimic" the host by possessing similar colors and/or having appendages that resemble parts of the crinoid, 


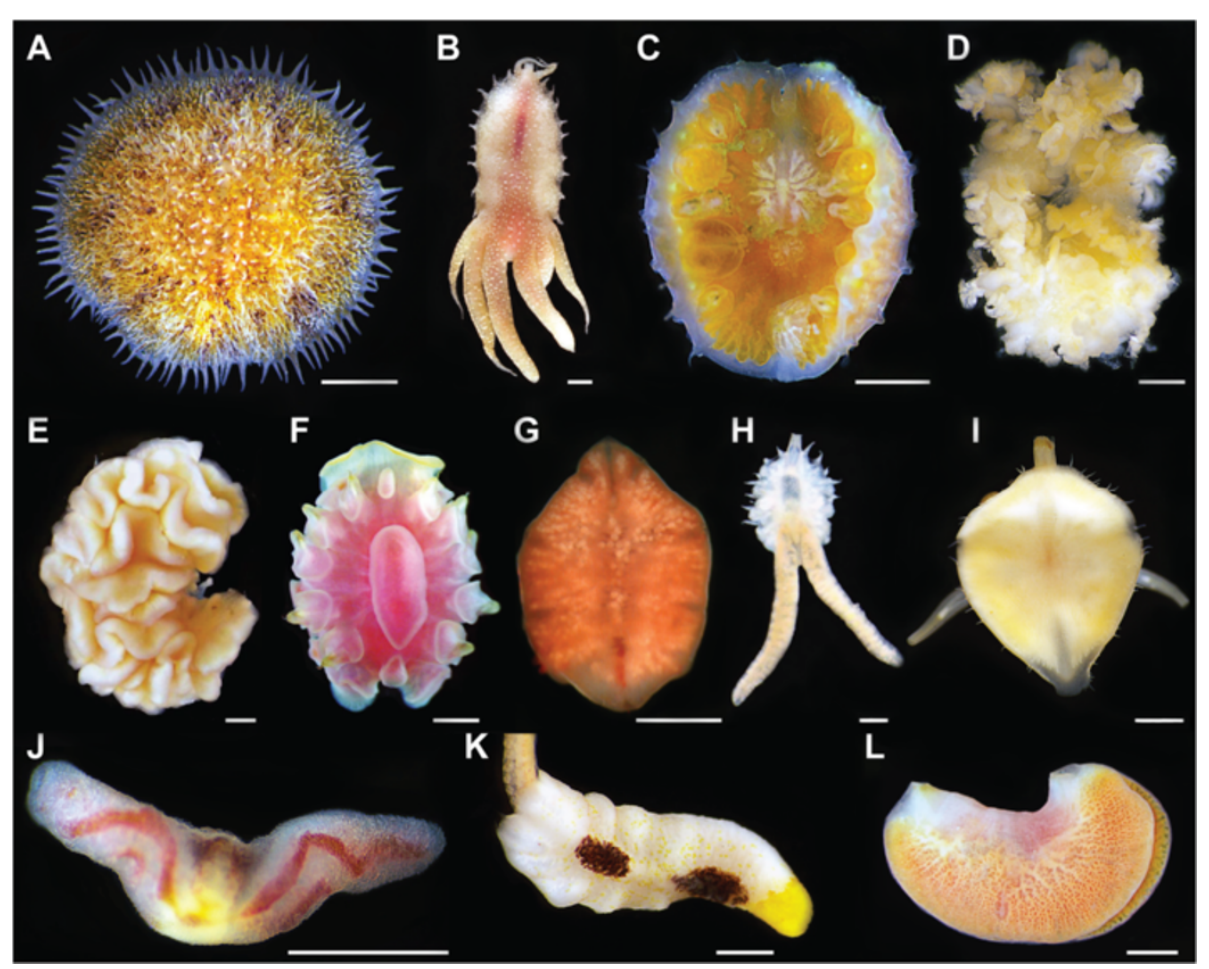

Figure 1 Diversity of Myzostomida. (A) Myzostoma capitocutis (Myzostomatidae), free-living. (B) Myzostoma eeckhauti nomen nudum (Summers \& Rouse, in press.) (Myzostomatidae), free-living. (C) Pulvinomyzostomum inaki nomen nudum (Summers \& Rouse, in press.)

(Pulvinomyzostomatidae), found in or near mouth. (D) Mesomyzostoma sp. (Myzostomatidae, previously Mesomyzostomatidae), resides within the host's coelom. (E) Asteromyzostomum grygieri nomen nudum (Summers \& Rouse, in press.) (Asteromyzostomatidae), recovered externally with mouth pierced through body wall. (F) Notopharyngoides aruensis (Myzostomatidae), found in mouth. (G) Protomyzostomum roseus nomen nudum (Summers \& Rouse, in press.) (Protomyzostomatidae), found within the host's coelom. (H) Myzostoma divisor (Myzostomatidae), free-living. (I) Notopharyngoides platypus (Myzostomatidae), resides permanently in cysts. (J) Contramyzostoma bialatum (Myzostomatidae, previously Endomyzostomatidae), resides permanently in cysts. (K) Myzostoma longitergum (Myzostomatidae), free-living. (L). Endomyzostoma neridae nomen nudum (Summers \& Rouse, in press.) (Endomyzostomatidae), lives within galls. A, D, I, K—Raja Ampat, Indonesia. B, J—Madang Habor, Papua New Guinea. C-Costa Rica. E, H—Antarctica. F-Lizard Island, Australia. G-Monterey, California. L-Dili, East Timor. Scale bars 1 mm (A, D-G, I-L); $0.5 \mathrm{~mm}(\mathrm{H}) ; 0.2 \mathrm{~mm}(\mathrm{~B}, \mathrm{C})$.

for example, extensions that look like pinnules [6-8]. Other myzostomids reside in galls (hard) or cysts (soft) along the host's food grooves, or within the host's mouth, digestive system, coelom, or gonads [4-6,9]. Those living on the outside of the animal and within galls, cysts, the mouth, and digestive track are presumed to be stealing the host's food, while those within the coelom and gonads are believed to be eating the host directly $[4,6]$.

Though once controversial, molecular and morphology analyses now support myzostomids as part of the annelid radiation, but the relationship of Myzostomida to other annelid groups remains unresolved [10-16]. Three published phylogenies have treated relationships within Myzostomida. The first two are based solely on morphology [6,17], and the most recent is based on molecular data (three genes) from 37 taxa [18]. Grygier [6] and Lanterbecq et al. [18] revealed problems with the classification within the group, though no changes from the system proposed by Jägersten [17] (Table 1, left column) have yet been made. The molecular phylogeny of Lanterbecq et al. [18] recovered two major clades, one composed of gall-, cyst-, and mouth-dwelling taxa associated with crinoids, and the other including mostly free-living taxa, along with cyst, mouth, and internal forms. Based on this phylogeny, they proposed the ancestral state for Myzostomida to have been an external form found on crinoids and argued for independent emergences of gall, cyst, and internal forms $[18,19]$.

The variety of life histories combined with dependence on an echinoderm host makes Myzostomida an interesting lineage in which to explore the evolutionary effects of obligate symbiosis and relationships with their echinoderm hosts. Signs of suspected myzostomid infestations have been found on fossilized stalked crinoids from the early Jurassic [20] and possibly as far back as the Silurian [21]. A previous coevolutionary analysis of sixteen hosts and myzostomids recovered significant cophylogeny [22]. 
Table 1 Classifications of Myzostomida Graff, 1877

\begin{tabular}{|c|c|}
\hline Previous classification & Revised classification \\
\hline Pharyngidea Jägersten, 1940 & ${ }^{*}$ Asteriomyzostomatidae Jägersten, 1940 \\
\hline Asteriomyzostomatidae Jägersten, 1940 & *Asteriomyzostomum Jägersten, 1940 (2 species) \\
\hline Asteriomyzostomum Jägersten, 1940 & Asteromyzostomatidae Wagin, 1954 \\
\hline Asteromyzostomatidae Wagin, 1954 & Asteromyzostomum Wagin, 1954 (3 species) \\
\hline Asteromyzostomum Wagin, 1954 & Eenymeenymyzostomatidae Summers \& Rouse \\
\hline Endomyzostomatidae Perrier, 1897 & Eenymeenymyzostoma Summers \& Rouse (1 species) \\
\hline Contramyzostoma Eeckhaut \& Jangoux, 1995 & Endomyzostomatidae Perrier, 1897 \\
\hline Endomyzostoma Perrier, 1897 & Endomyzostoma Perrier, 1897 (14 species) \\
\hline Mycomyzostoma Eeckhaut, 1998 & Myzostomatidae Beard, 1884 \\
\hline Mesomyzostomatidae Stummer-Traunfels, 1923 & ^Contramyzostoma Eeckhaut \& Jangoux, 1995 (1 species) \\
\hline Mesomyzostoma Remscheid, 1918 & Hypomyzostoma Perrier, 1897 (10 species) \\
\hline Protomyzostomatidae Stummer-Traunfels, 1923 & ^Myzostoma Leuckart, 1827 (115 species) \\
\hline Protomyzostomum Fedetov, 1912 & Mesomyzostoma Remscheid, 1918 (2 species) \\
\hline Pulvinomyzostomatidae Jägersten, 1940 & ^Notopharyngoides Uchida, 1992 (3 species) \\
\hline Pulvinomyzostomum Jägersten, 1940 & Protomyzostomatidae Stummer-Traunfels, 1923 \\
\hline Stelechopodidae Graff, 1884 & Protomyzostomum Fedetov, 1912 (4 species) \\
\hline Stelechopus Graff, 1884 & Pulvinomyzostomatidae Jägersten, 1940 \\
\hline Proboscidea Jägersten, 1940 & Pulvinomyzostomum Jägersten, 1940 (1 species) \\
\hline Myzostomatidae Beard, 1884 & *Stelechopodidae Graff, 1884 \\
\hline Hypomyzostoma Perrier, 1897 & *Stelechopus Graff, 1884 (1 species) \\
\hline Myzostoma Leuckart, 1827 & Family uncertain \\
\hline Notopharyngoides Uchida, 1992 & *Mycomyzostoma Eeckhaut, 1998 (1 species) \\
\hline
\end{tabular}

Previous classification (Jägersten [17]; Grygier [6]) shown in left column. Classification as revised here, with the number of currently described species for each genus, shown in the right column. * indicate groups with no molecular data available. $\wedge$ denote paraphyletic/polyphyletic taxa based on the molecular phylogeny in Figure 2.

In this paper we sample a substantially broader range of myzostomid species with accompanying DNA sequences, allowing a reassessment of the phylogeny and evaluation of symbiotic lifestyles, host specificity, and host affinity. We revise the classification of Myzostomida accordingly and re-examine congruence between the phylogeny of myzostomids and their hosts.

\section{Results}

\section{Phylogeny of Myzostomida}

Additional file 1: Table S1 lists the nominal species and terminals used to assess myzostomid phylogeny, including the genes sequenced for this study and those obtained from GenBank. The maximum parsimony (MP) and maximum likelihood (ML) results for each gene partition are summarized in Additional file 1: Table S2. Results from individual genes were basically congruent with each other, and with the combined data analyses (MP, ML, and Bayesian), and are not shown here. The aligned sequence data from the four genes (COI, 16S, 18S, H3) yielded a concatenated 'complete' dataset of 3019 characters with 1187 parsimony informative sites and 252 variable, but uninformative, sites. The 'restricted' dataset (with 16S, 18S, and H3 Gblocked and third positions of COI excluded) had 2501 characters, with 908 parsimony informative sites and 182 variable, but uninformative, sites.

The ML and Bayesian analyses of the complete $(\mathrm{ML}=-\ln$ 38806.84) and restricted ( $M L=-\ln 26899.17)$ datasets gave the same tree topology (Figure 2). Endomyzostoma Perrier, 1897 (living in galls or cysts on crinoids) formed a wellsupported clade sister to all other myzostomids. Within this latter clade, Asteromyzostomum Jägersten, 1940 (associated with a seastar) was found with high support as sister to Protomyzostomum Fedetov, 1912 (living in ophiuroids) and this clade was then sister to the remaining myzostomids found on crinoids. Myzostoma cirripedium Graff, 1885, a freeliving form on a stalked crinoid (previously found within Endomyzostoma and referred to this genus [18]), was sister to the well-supported clade of Pulvinomyzostomum Jägersten, 1940 and the remaining myzostomids. The placement of Myzostoma cirripedium requires that it be placed in a new genus, Eenymeenymyzostoma n. gen. (see Taxonomy section). Pulvinomyzostomum, with type species 


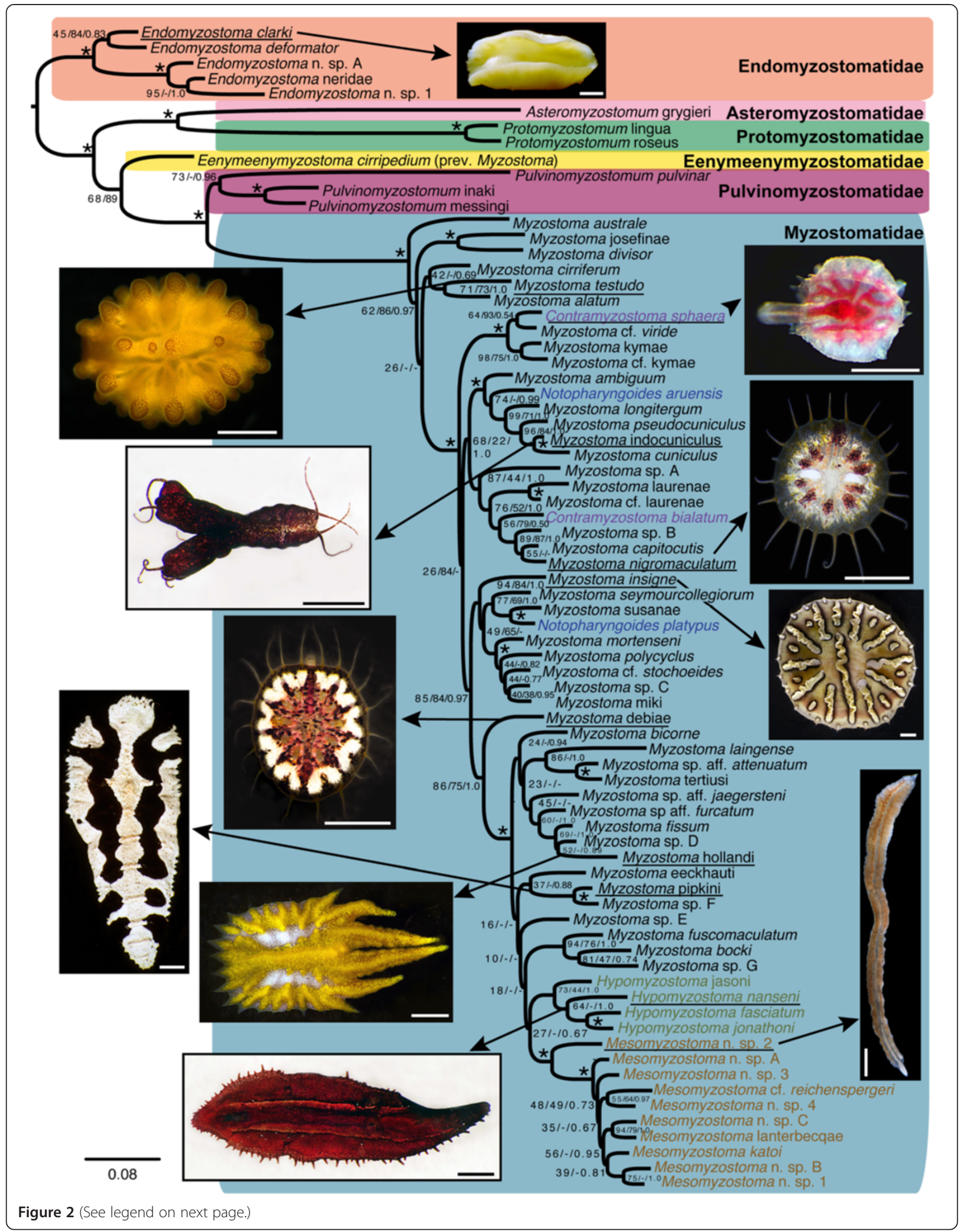


Figure 2 Phylogeny of Myzostomida. Maximum likelihood (ML) tree inferred from the concatenated four-gene dataset, all positions included. Symbols near nodes refer to bootstrap (BS) and jackknife (JK) support scores and posterior probabilities (PP), for ML, maximum parsimony (MP), and Bayesian analyses, respectively. An asterisk indicates nodes with $>90 \%$ bootstrap and jackknife support and $>0.95$ posterior probability. Other scores are represented BS/JK/PP. A hyphen is given for nodes not recovered in MP or Bayesian analyses. Colored boxes surround clades delimited in the taxonomic revision provided herein. Photographs correspond to underlined taxa. Scale bars $1 \mathrm{~mm}$. Specific names written in plain text are for species described in a separate publication - Summers \& Rouse, in press. These names are disclaimed for nomenclatural purposes under ICZN 8.3 and are not made available through this publication.

Pulvinomyzostomum pulvinar (Graff, 1884), formed a clade (through likelihood, but not parsimony analyses) with two other undescribed myzostomid species. Pulvinomyzostomum inaki nomen nudum (Summers and Rouse in press) has the same lifestyle as $P$. pulvinar (in the mouth of the crinoid), while Pulvinomyzostomum messingi nomen nudum (Summers and Rouse in press) is a free-living form on its stalked hyocrinid host.

The MP analysis of the complete dataset yielded 100 most parsimonious trees, length 9386. The MP analysis of the restricted dataset yielded 56 most parsimonious trees with a tree length of 5451. The MP results were similar to each other and largely congruent with the ML and Bayesian analyses, but the grade of taxa shown in Figure 2 with respect to Myzostomatidae, was instead a grade with respect to Endomyzostoma (Additional file 1: Figure S1). Also, the three species forming the Pulvinomyzostomum clade in the ML and Bayesian analyses were not monophyletic in the MP results. Two basic topologies were considered for the interpretation of the transformations, the first ML- and Bayesian- based (Figure 2) and the second MP-based (Additional file 1: Figure 1).

With regard to the relationships within the wellsupported Myzostomatidae, all MP, ML, and Bayesian analyses showed Myzostoma Leuckart, 1827 as paraphyletic with the genera Contramyzostoma Eeckhaut \& Jangoux, 1995, Hypomyzostoma Perrier, 1897, Mesomyzostoma Remscheid, 1918 and Notopharyngoides Uchida, 1992 nested inside (Figure 2, Additional file 1: Figure S1). Relationships in the MP analyses varied among the species of Myzostoma in the various shortest trees for the complete and restricted analyses and between these analyses and the ML and Bayesian analyses. This is reflected in the poor support for many of the nodes across Myzostomatidae (Figure 2). What all analyses did show was that Myzostoma australe Rouse, 2003 was the sister group to all other Myzostomatidae.

The ML and Bayesian analyses presented a monophyletic Hypomyzostoma as a poorly supported sister-group to a well-supported Mesomyzostoma clade (Figure 2), as did some MP trees, though with poor support. Hypomyzostoma has the type species H. folium (Graff, 1884), which was not available for this study. However, based on morphology and following Lanterbecq et al. [18], we apply the name Hypomyzostoma to the clade comprising four nominal species ( $H$. jonathoni nomen nudum (Summers \& Rouse, in press.), H. jasoni nomen nudum (Summers \& Rouse, in press), H. nanseni (Graff, 1887), and $H$. fasciatum (Remscheid, 1918)).

All results recovered Contramyzostoma as polyphyletic, with C. sphaera Eeckhaut, Grygier, \& Deheyn, 1998 as the sistergroup to Myzostoma cf. viride, and C. bialatum Eeckhaut \& Jangoux, 1995, the type species of the genus, as sister to another clade of Myzostoma species. Notopharyngoides was also consistently polyphyletic, with $N$. aruensis (Remscheid, 1918) and N. platypus (Graff, 1887) well separated and sister groups to different clades of Myzostoma.

With regards to family-ranked taxa, the concatenated ML and Bayesian analyses (see Figure 2) returned four of the current families as clades: Asteromyzostomatidae (monotypic), Protomyzostomatidae, Pulvinomyzostomatidae, and Mesomyzostomatidae (Table 1-left column), though the latter taxon rendered Myzostomatidae paraphyletic. The MP analyses did not recover what is delineated as Pulvinomyzostomatidae in Figure 2 as a clade (see Additional file 1: Figure S1). The concatenated ML, Bayesian, and MP analyses recovered Endomyzostomatidae as polyphyletic (two genera sequenced). Endomyzostoma formed a clade that was sister to all other myzostomid terminals (Figure 2) and is here retained as Endomyzostomatidae, while the two terminals of Contramyzostoma were nested within clades composed primarily of Myzostoma (Figure 2, Additional file 1: Figure S1). Myzostomatidae was recovered as paraphyletic (all three genera sequenced), owing to the placement of Contramyzostoma (Endomyzostomatidae) and Mesomyzostoma (Mesomyzostomatidae) among the various Myzostomatidae terminals, and these taxa are now referred to this family. Figure 2 and Table 1 (right column) indicate the revised family taxon memberships and names.

\section{Lifestyle transformations}

Most myzostomids live externally on their host following a period of development in a cyst (i.e., cyst-to-free-living). This condition evidently arose once in both the ML/Bayesian and MP topologies, and is found in Eenymeenymyzostoma n. gen. and Myzostomatidae (Figure 3). Gall-forming myzostomids were recovered as a single clade within Endomyzostoma. Adult cyst-dwelling myzostomids were 


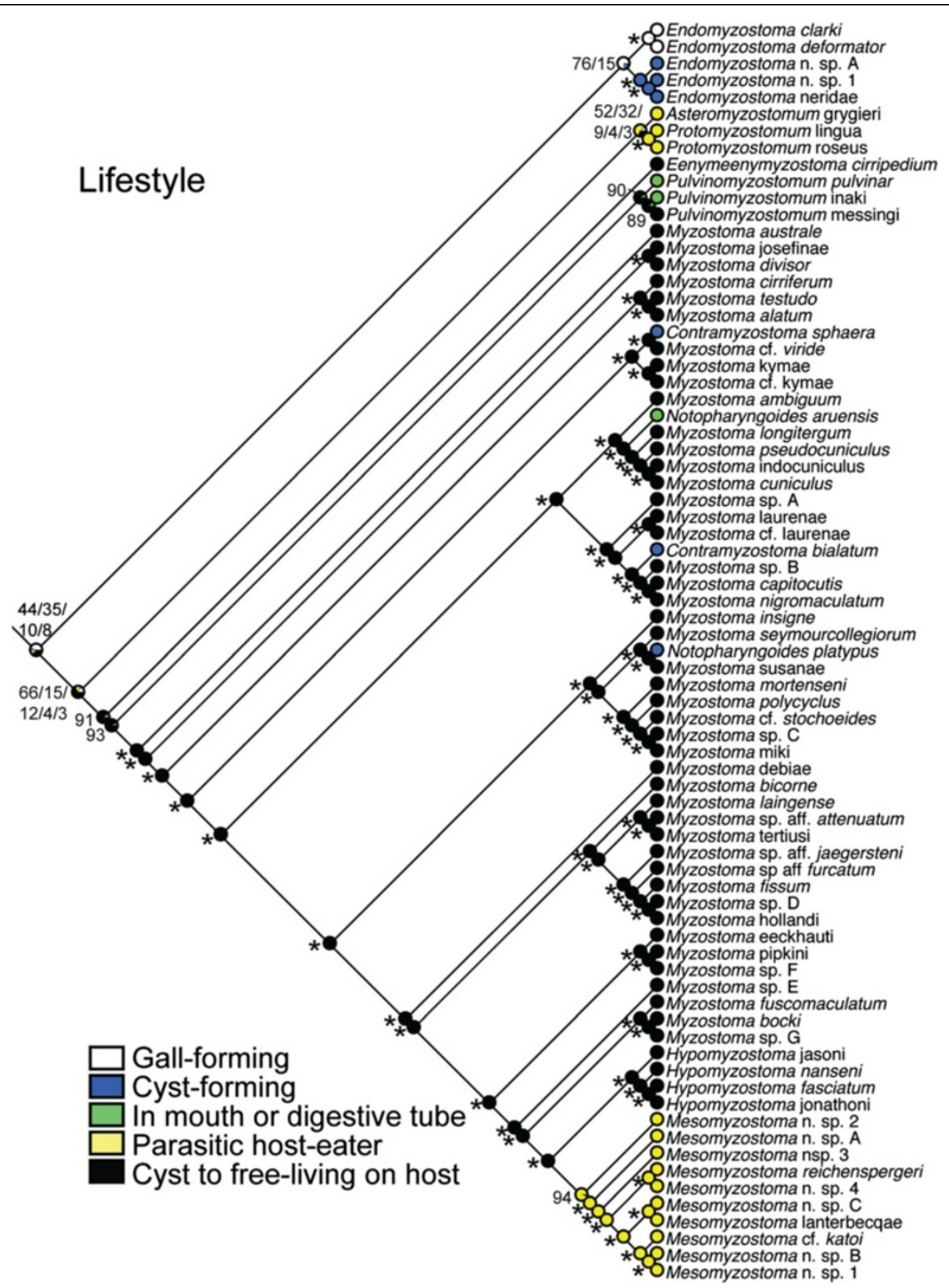

Figure 3 Maximum likelihood transformations for myzostomid lifestyle. Number and symbols near nodes refer to proportional likelihood estimations. An asterisk indicates nodes with an estimated proportional likelihood of $>95 \%$. Other scores are provided in order of most likely states and separated by a forward slash when applicable. See Figure 2 regarding non-italicized names.

recovered in both Endomyzostoma and Myzostomatidae. In Endomyzostoma, these cyst-forming taxa were a clade. Three other adult cyst-dwellers (Contramyzostoma sphaera, Contramyzostoma bialatum, and Notopharyngoides platypus) were distributed across Myzostomatidae, each sharing a most recent common ancestor with a form that transitioned from a cyst to an external adult life. In all of these cases, this ancestor was estimated to have been cyst to freeliving (prop. likelihood 1.00). Two taxa found in the mouth or digestive tube were in Pulvinomyzostomum and one in
Myzostomatidae (Notopharyngoides aruensis), each arguably arising from a cyst to free-living ancestor (Figure 3). Host-eating forms were within Asteromyzostomum (found on/in asteroids), Protomyzostomum (living in ophiuroids), and Mesomyzostoma (living within crinoids). For both ML/ Bayesian and MP topologies, internal host-eating was most likely the plesiomorphic condition for Mesomyzostoma (prop. likelihood 0.94) and possibly Asteromyzostomum + Protomyzostomum clades (prop. likelihood 0.58 and 0.52 respectively). 


\section{Patterns of host use and specificity}

Figure 4A shows transformations for general host type. Association with asteroids and ophiuroids is restricted to Asteromyzostomum and Protomyzostomum, respectively. Eenymeenymyzostoma n. gen. resides exclusively on stalked crinoids, and the sequenced Myzostomatidae only inhabit feather stars. Endomyzostoma and Pulvinomyzostomum infect both stalked and feather star crinoids. The ML/Bayesian topology suggests a stalked crinoid was the ancestral host for Myzostomida (prop. likelihood 0.87), with one transition to asteroids (Asteromyzostomum), one to ophiuroids (Protomyzostomum), and three transitions to feather stars (in Endomyzostoma and the clade of Pulvinomyzostomatidae + Myzostomatidae, with a reversal back to a stalked crinoid for Pulvinomyzostomum messingi nomen nudum). Transformations on the MP topology suggest a feather star crinoid as the ancestral host (prop. likelihood 0.87), with one transition to asteroids, one to ophiuroids, and two or three transitions to stalked crinoids (for Pulvinomyzostomum messingi nomen nudum, Eenymeenyzostoma cirripedium, and in Endomyzostoma, or Pulvinomyzostomum messingi nomen nudum and the ancestor of E. cirripedium + Endomyzostoma, with a reversal to stalked crinoids in Endomyzostoma). Six most parsimonious reconstructions (MPRs) were found for host type on both ML/Bayesian and MP topologies, the variation due to unresolved nodes for Asteromyzostomum and Protomyzostomum.

Figure 4B shows the maximum likelihood transformations for major host clades, which mostly correspond to family-level classification of crinoids and also include Asteroidea de Blainville, 1830 and Ophiuroidea Gray, 1840. Isocrinid stalked crinoids are hosts to gall-Endomyzostoma and cyst-to-free-living Eenymeenymyzostoma n. gen., while Pulvinomyzostomum messingi nomen nudum is found on a hyocrinid stalked crinoid. Among feather stars, species of Antedonidae Norman, 1865 host two Pulvinomyzostomum taxa and two Myzostomatidae taxa. Myzostoma australe is found on a Ptilometridae AH Clark, 1914 and M. divisor Grygier, 1989 and Myzostoma josefinae nomen nudum (Summers \& Rouse, in press.) on Zenometridae AH Clark, 1909. Comatulidae Fleming, 1828, Mariametroidea AH Clark, 1909, and Tropiometridae AH Clark, 1908 all host taxa within Myzostomatidae. The large number of MPRs

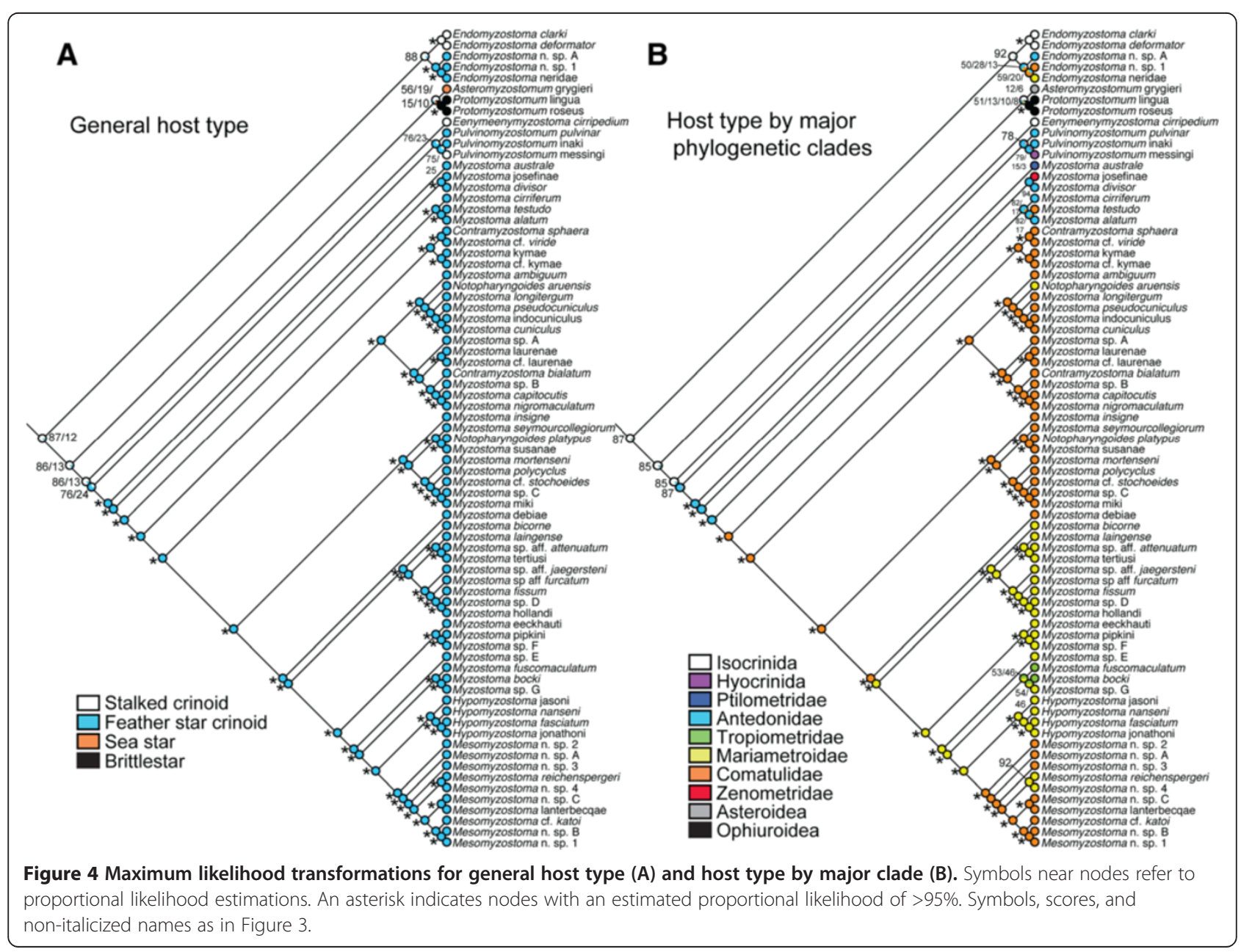


for both ML/Bayesian and MP topologies (132 and 66 respectively) suggest multiple scenarios regarding switches among major host clades, especially at the family-level for myzostomids. Within Myzostomatidae, both topologies suggest two transitions to association with Comatulidae, three to four switches to Mariametroidea, and one or two inhabitations of Tropiometridae.

Additional file 1: Figure S2 presents the distribution of host specificity on the ML/Bayesian topology. Occurrence on only one host is most common, and is present in all families except Eenymeenymyzostomatidae $\mathrm{n}$. fam. The 12 MPRs suggest that infestation of more than one host arose multiple times independently.

\section{Comparison of myzostomid and host phylogenies}

Figure 5 shows associations among myzostomids and their hosts (88 links in total). The host was known for 69 of 75 myzostomid terminals (Additional file 1: Table
S1). Additional file 1: Table S3 lists the nominal species and 53 terminals used to estimate the host phylogeny. The MP and ML results for the concatenated datasets and each gene partition are provided in Additional file 1: Table S2. The overall phylogeny of the 69myzostomid phylogeny was congruent with that recovered for all included terminals. For hosts, there were four major well-supported clades: stalked crinoids (Isocrinida and Hyocrinida), asteroids and ophiuroids, one family of feather stars (Comatulidae), and all other feather stars (Figure 5).

Most clades of myzostomids were associated with specific clades of hosts (branches shown in the same color Figure 5). Exceptions include Pulvinomyzostomum (the two included terminals associate with a stalked and feather star crinoid, respectively), Notopharyngoides aruensis, Mesomyzostoma (taxa are found within two clades of feather stars), and Endomyzostoma (specimens infest

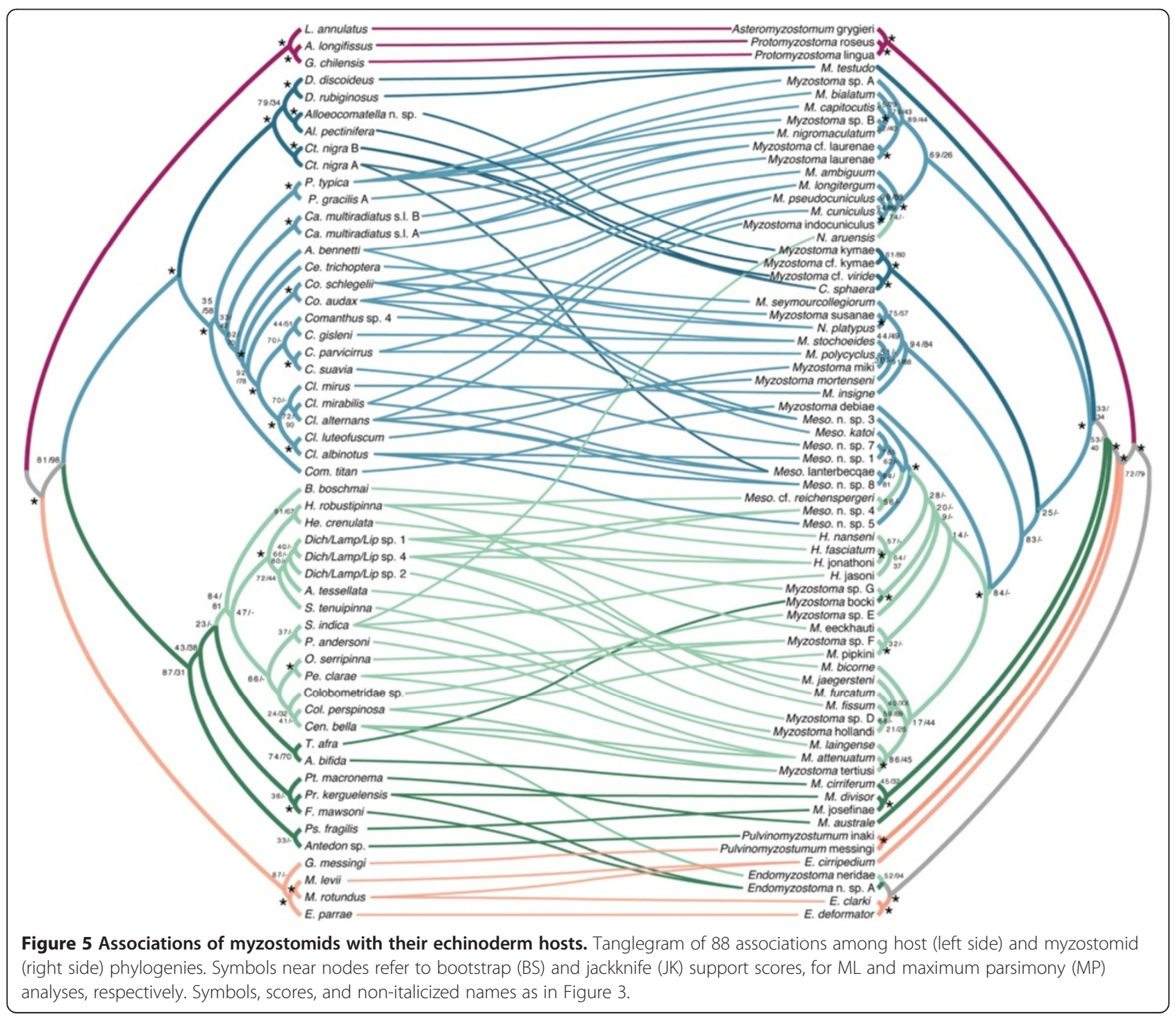


stalked crinoids and two clades of feather stars). Endomyzostoma species are known from all the crinoid groups referenced here (as in Figure 4B) and along with Pulvinomyzostomum and Mesomyzostoma, are likely considerably undersampled.

Parafit analysis of myzostomids and their hosts rejected the null hypothesis of random association (ParaFitGlobal = 2439.93156; $\mathrm{P}=0.00050$ ). Three of the 88 individual links were significant (for terminals of Asteromyzostomum and Protomyzostomum) (prob1 and prob2 <0.016). JANE analyses under default settings led to 4297 reconstructions (cost =139) for the ML/Bayesian-rooted topology (e.g., Figure 5). Duplication with host switch was most used (4041), followed by 29-30 losses, 19 failures to diverge, 18 cospeciation events, and 9-10 duplications. The mean costs were estimated as 377 (STD 30) for random associations and 331 (STD 25) for random parasite topology.

\section{Discussion}

\section{Taxonomic implications}

This molecular study incorporated 75 myzostomid terminals representing six of the eight subfamilies and nine of the 12 genera. Previously, Lanterbecq et al. [18] offered the only hypothesis for myzostomid evolution based on molecular data. They incorporated three genes (one nuclear, two mitochondrial) for 37 species from nine myzostomid genera, and recovered taxa associated with ophiuroids (members of Protomyzostomatidae) within Mesomyzostomatidae [18], a family otherwise containing species living in the coelom and gonads of crinoids. They also found Mesomyzostomatidae and a terminal attributed to Asteromyzostomum (an associate of an asteroid) nested among free-living terminals of Myzostomatidae [18].

Our results recovered four of the families as monophyletic: Asteromyzostomatidae, Protomyzostomatidae, Pulvinomyzostomatidae, and Mesomyzostomatidae (Table 1-left column). Mesomyzostoma was recovered within Myzostomatidae as in the phylogeny of Lanterbecq et al. [18], but Asteromyzostomum and Protomyzostomum were instead recovered as a well-supported clade sister to Pulvinomyzostomum and Myzostomatidae. We sequenced recently collected Asteromyzostomum specimens from the same locality and host species and Protomyzostomum specimens from similar hosts to those used in Lanterbecq et al. [18]. Since the previously sequenced material was old and the amplified sequences were short and very similar to other reads amplified in the same study, we suspect that these previous sequences are inaccurate. Amended identifications for these, and other specimens sequenced in Lanterbecq et al. [18] are provided in the caption of Additional file 1: Table S1.

Molecular results from ML, MP, and Bayesian analyses recovered both myzostomid families that have more than one genus, Endomyzostomatidae and Myzostomatidae, as paraphyletic. We restrict Endomyzostomatidae to include only Endomyzostoma and transfer Contramyzostoma to Myzostomatidae (Table 1, right column). Eeckhaut and Jangoux [23] assigned Contramyzostoma to Endomyzostomatidae based on its cyst-dwelling lifestyle (see [6]). Contramyzostoma possess a salivary gland arrangement resembling that of Myzostoma, and Grygier [6] suggested their morphological affinity to Myzostomatidae. Also, cyst forms of Endomyzostoma may be gonochoric and have been found with dwarf males, while those of Myzostomatidae are generally simultaneous hermaphrodites and have long protrusible penes to inseminate mates in nearby cysts (see $[6,19])$. To make Myzostomatidae monophyletic, Mesomyzostoma (Mesomyzostomatidae) is also moved to this family (Table 1, right column), resulting in Mesomyzostomatidae becoming a junior synonym of Myzostomatidae. To accommodate Myzostoma cirripedium Graff, 1885, a species recovered well outside all other members of Myzostoma, Eenymeenymyzostoma n. gen. and Eenymeenymyzostomatidae n. fam. are erected here (see Taxonomy section).

This study recovered four genera including more than one terminal as monophyletic (Endomyzostoma, Mesomyzostoma, Pulvinomyzostomum, and Protomyzostomum), one genus as paraphyletic (Myzostoma) (polyphyletic before erection of Eenymeenymyzostoma n. gen. for Myzostoma cirripedium), and two genera as polyphyletic (Contramyzostoma and Notopharyngoides). Although Myzostoma is clearly paraphyletic, this genus will not be revised here. The type species for Myzostoma is $M$. cirriferum Leuckart, 1836, which was recovered as part of a relatively basal grade of terminals in Myzostomatidae (Figure 2). There was little support in this region of the topology and there was conflict among the various ML, Bayesian, and MP analyses. Revising the membership of Myzostoma to make it monophyletic based on Figure 2 would restrict the genus to just a few species, and so require name changes for all the remaining species currently in the genus. We refrain from doing so until a more robust phylogeny is obtained.

The polyphyly found here for the cysticolous Contramyzostoma (two species) and Notopharyngoides (three species) is not unexpected. The morphology of Contramyzostoma sphaera differs considerably from the type species, C. bialatum, and Eeckhaut et al. [24] only tentatively assigned it to this genus. As we are not fully revising the taxonomy within Myzostomatidae, we simply remove $C$. sphaera from the same genus as $C$. bialatum and refer to it as Myzostoma sphaera. Sequenced taxa of Notopharyngoides differ in the location of the proboscis as well as where they live on the host. The proboscis is ventral in $N$. platypus, which resides in cysts on the oral surface, and dorsal in $N$. aruensis, which occupies the mouth. We did not have sequences of the type species, Notopharyngoides ijimai (Hara \& Okada, 1921), which 
has a dorsal proboscis, and we thus leave Notopharyngoides as polyphyletic pending further study.

\section{Evolution of lifestyles}

Taxa that steal the host's food (e.g., cyst-to-free-living, cyst, gall, and mouth/digestive forms) were recovered as a grade (Figure 3). Mouth and digestive-system dwellers (some Pulvinomyzostomum, some Notopharyngoides) and permanent cyst forms within Myzostomatidae (Contramyzostoma, some Notopharyngoides) were arguably derived from cyst-to-free-living ancestors. These permanent cyst-forms may have arisen via paedomorphosis, since, as far as is known for myzostomid development, free-living forms initially develop in a cyst [6]. Observations of mouth-dwelling taxa are consistent with a freeliving myzostomid relocating to a stationary position in the mouth. Females of Pulvinomyzostomum pulvinar occupy the stomach, esophagus, and mouth, while smaller males are found either on the body of the female or free-living on the host [17].

Forms in which the adults consume the host directly have arguably arisen either twice independently (Figure 3 ) - in the ancestor of Asteromyzostomum and Protomyzostomum (which reside in asteroids and ophiuroids) and in the ancestor of Mesomyzostoma (which live within crinoids) - or three times (separately in Asteromyzostomum and Protomyzostomum). Finding and studying internal myzostomids requires dissection of the host, and their diversity is likely considerably undersampled. Lanterbecq et al. [18] considered internal and external host-eaters, gall and cyst foodstealers, and some stationary free-living forms as parasites; as a result, they suggested multiple independent switches to 'parasitism'. Although all myzostomid forms could be called parasites, differentiating host-eaters and food-stealers as done here reduces the emergence of host consumption (which in some cases can lead to castration (e.g., $[25,26]$ ) to two or possibly three times during the evolution of myzostomids.

The morphology and lifestyle of the ancestral myzostomid form is not clear, especially when the closest annelid relative remains elusive. Likelihood estimates for the ancestral node for the ML/Bayesian-rooted topology were split between gall and cyst-to-free-living forms, with cyst and internal forms also likely. Based on this transformation, a free-living lifestyle (following development in a cyst) arose once on a deep-sea stalked crinoid (Figures 3). When considering the MP-rooted topology, a free-living form is estimated for the ancestral node, as suggested in previous studies $[18,19]$.

\section{Patterns of host associations}

High host specificity and phylogenetic conservatism in host use was observed (Additional file 1: Figure S2; Figure 4), the latter likely contributing to the non- random pattern of associations among hosts and myzostomids. Myzostomids have a planktonic larval stage $[27,28]$, and their crinoid hosts may occur in multispecies assemblages in close physical proximity [29]. These two factors make this result surprising, suggesting that myzostomids are restricted to certain echinoderms and switch mainly to evolutionarily related hosts. Such a pattern of phylogenetic conservatism in host use is widespread among a variety of parasites and hosts, including gall-inducing insects (see [30]), brood parasites (e.g., [31,32]), fish parasites [33], and many others (see [34] for a general review). Specificity in this system may be promoted through a number of mechanisms. Myzostomids may only be capable of infesting certain echinoderm groups, but little is currently known about recruitment and subsequent development of myzostomid larvae. In experimental studies, Eeckhaut and Jangoux [27] observed the host crinoid (Antedon bifida) expelling Myzostoma cirriferum larvae from its food grooves using its podia and also regurgitating ingested larvae. They did find that $M$. cirriferum larvae could recruit onto the crinoid at a specific developmental stage. A comparative study of recruitment and reproductive success across a range of myzostomids and their hosts could be a first step in understanding whether or not myzostomids are equally capable of infesting a range of crinoids, or rather if they have specialized tactics for better success on certain species.

Examination of the co-phylogenetic structure of Myzostomida and their hosts does not support strict topological congruence. Although the global null hypothesis of independent association using ParaFit was rejected, only three links out of the 88 associations were significantly concordant. These links were for myzostomids associated with asteroids and ophiuroids. Rather than a signal of 'co-speciation,' this congruence is likely an artifact of the small number of known asteroids and ophiuroids that are infected by myzostomids. In eventbased analyses, host switches and duplications were mostly used to reconcile the myzostomid and host trees, numbering 40-41 compared to 18 for co-speciations. Acknowledging that event reconstructions are best used for exploratory purposes rather than explanatory ones (and that we did not perform an exhaustive exploration of possible cost schemes or topologies), the high number of events other than 'co-speciation' and the discordance found for the majority of links using distance methods, leads us to infer that this system is not a model of strict phylogenetic 'co-speciation.' Global concordance could have resulted from a number of mechanisms, including, but not limited to, host tracking, vicariance, and cospeciation (see $[35,36]$ for reviews). Inferring the mechanisms underlying this pattern requires experimental follow-up. 


\section{Taxonomic changes}

Eenymeenymyzostomatidae $\mathrm{n}$. fam. Summers \& Rouse

Included genera. Eenymeenymyzostoma n. gen. Summers \& Rouse.

\section{Eenymeenymyzostoma n. gen. Summers \& Rouse}

Type species. Myzostoma cirripedium Graff, 1885 - Sagami Bay, Japan, $218 \mathrm{~m}$.

Etymology. This name was chosen for its assonance (suggested by Charles Messing).

Remarks. To accommodate Myzostoma cirripedium Graff, 1885, a species recovered well outside all other members of Myzostoma, Eenymeenymyzostoma n. gen. and Eenymeenymyzostomatidae n. fam. are erected here. Eenymeenymyzostoma n. gen. is currently monotypic. Sequences for this species were referred to as Endomyzostoma n. sp. 2 in Lanterbecq et al. [18]. Myzostoma metacrini McClendon, 1906 is a junior synonym of E. cirripedium. Other potential members of Eenymeenymyzostoma n. gen. include ten other freeliving myzostomid species described from stalked crinoids (excluding Pulvinomyzostomum messingi nomen nudum (Summers \& Rouse, in press)); molecular data are not currently available for these taxa.

\section{Endomyzostomatidae Perrier, 1897}

\section{Included genera. Endomyzostoma Perrier, 1897}

Remarks. Endomyzostomatidae as previously delineated (including Contramyzostoma, Endomyzostoma, and Mycomyzostoma) was recovered as polyphyletic in the molecular analyses (e.g., Figure 2). To make Endomyzostomatidae monophyletic, it is restricted here to include only Endomyzostoma. Contramyzostoma is transferred to Myzostomatidae and the placement of Mycomyzostoma is uncertain until specimens are sequenced.

\section{Myzostomatidae Beard, 1884}

Included genera. Contramyzostoma Eeckhaut \& Jangoux, 1995; Hypomyzostoma Perrier, 1897; Myzostoma Leuckart, 1827; Mesomyzostoma Remscheid, 1918; Notopharyngoides Uchida, 1992.

Remarks. To make Myzostomatidae monophyletic, Contramyzostoma (previously Endomyzostomatidae) and Mesomyzostoma (previously Mesomyzostomatidae) are transferred to this family. This results in Mesomyzostomatidae becoming a junior synonym of Myzostomatidae.

\section{Contramyzostoma Eeckhaut \& Jangoux, 1995}

Type species. Contramyzostoma bialatum Eeckhaut \& Jangoux, 1995

Remarks. The two previous members of Contramyzostoma, C. bialatum and C. sphaera were not recovered within a single clade. To eliminate this polyphyly, we remove $C$. sphaera from the same genus as $C$. bialatum and refer to it as Myzostoma sphaera. As Myzostoma remains non-monophyletic (see Figure 2), Contramyzostoma will likely incorporate more members once this genus is resolved (e.g., Myzostoma nigromaculatum, Myzostoma capitocutis, Myzostoma sp. A, Myzostoma sp. B, and Myzostoma laurenae nomen nudum (Summers \& Rouse, in press).

\section{Note concerning specific names}

Specific names written in plain text within this work are disclaimed for nomenclatural purposes under ICZN 8.3 and are not made available through this publication.

\section{Conclusions}

Increased sampling and re-examination of previous work revised previous hypotheses concerning the systematics and evolution of Myzostomida, as well their relationship to their hosts. Contrary to previous reports of multiple switches among lifestyles [18], we found two or three transitions between food-stealing and host-eating. Taxa that dwell within the mouth or digestive system and some permanent cyst forms are arguably derived from cyst-to-free-living ancestors - possibly the result of a free-living form moving to the mouth and paedomorphic retention of the juvenile cyst. We recovered clades of myzostomids delimited more or less by their hostassociation. Phylogenetic conservatism in host use was observed for related myzostomid taxa, suggesting that myzostomes can only inhabit certain, and in most cases related, hosts.

\section{Methods}

\section{Taxon sampling}

Myzostomids and their hosts were collected chiefly using scuba. Animals collected at depths greater than $20 \mathrm{~m}$ were recovered using trawls or remotely operated vehicles (ROVs). Myzostomids were fixed in formalin, while hosts were preserved in ethanol or dried. Tissue subsamples of both myzostomids and hosts were placed in $95 \%$ ethanol or $20 \%$ DMSO buffer [37]. Specimens were deposited at or obtained from the American $\mathrm{Mu}$ seum of Natural History (AMNH), Australian Museum, Sydney, Australia (AMS); Muséum National d'Histoire Naturelle, Paris, France (MNHN); South Australian Museum, Adelaide, Australia (SAM); Benthic Invertebrate Collection, Scripps Institution of Oceanography, La Jolla, CA (SIO-BIC). Additional file 1: Table S1 and S3 lists locality details, voucher information, and host identifications. Live photographs were taken via Leica MZ8 or MZ9.5 stereomicroscopes with Canon Rebel T2i, T3i or T4i cameras and Speedlight flashes. 


\section{DNA extraction, amplification, and sequencing}

Genomic DNA was extracted from tissue subsamples using the Qiagen DNAeasy Tissue Kit following manufacturer protocols. For myzostomids, we sequenced four genes previously used for myzostomids (e.g., [18,25,38]). Two nuclear markers-18S rRNA (complete, approximately $1780 \mathrm{bp}$ ) and histone H3 (partial, approximately $350 \mathrm{bp}$ ), and two mitochondrial markers-16S rRNA (partial, approximately $550 \mathrm{bp}$ ) and Cytochrome oxidase subunit 1 (COI) (partial, approximately 700 bp). For hosts, four markers were sequenced: one nuclear-28S rRNA (incomplete, approximately $800 \mathrm{bp}$ ), and three mitochondrial-16S rRNA (partial, approximately 550 bp), Cytochrome oxidase subunit 1 (COI) (partial, approximately $1100 \mathrm{bp}$ ), and Cytochrome B (CytB) (partial, approximately $800 \mathrm{bp}$ ) following procedures of Rouse et al. [39]. PCR mixtures contained $12.5 \mu \mathrm{L}$ ProMega GoTaq Green DNA polymerase $\left(3 \mathrm{mM} \mathrm{MgCl}_{2}, 400 \mu \mathrm{M}\right.$ each dNTP, $1 \mathrm{U}$ Taq) and between 50-100 ng DNA.

For myzostomids, the complete $18 \mathrm{~S}$ rRNA nuclear gene (18S) for myzostomids was amplified in three overlapping fragments with the primer pairs: (1) $1 \mathrm{~F}$ (5'-TAC CTG GTT GAT CCT GCC AGT AG-3') and 5R (5'-CTT GCC AAA TGC TTT CGC-3') (950 bp); (2) 3 F (5'-GTT CGA TTC CGG AGA GGG A-3') and bi (5'-GAG TCT CGT TCG TTA TCG GA-3') (900 bp); (3) a.20 (5'-ATG GTT GCA AAG CTG AAA C-3') and 9R (5'-GAT CCT TCC GCA GGT TCA CCT AC-3') (850 bp) [40]. The reaction profiles were ( 1 and 3 ) $95^{\circ} \mathrm{C}$ for $180 \mathrm{~s}, 40$ cycles of $95^{\circ} \mathrm{C}$ for $30 \mathrm{~s}, 49^{\circ} \mathrm{C}$ for $30 \mathrm{~s}$, and $72^{\circ} \mathrm{C}$ for $90 \mathrm{~s}$, and finally $72^{\circ} \mathrm{C}$ for $480 \mathrm{~s}$; (2) $95^{\circ} \mathrm{C}$ for $180 \mathrm{~s}, 40$ cycles of $95^{\circ} \mathrm{C}$ for $30 \mathrm{~s}, 52^{\circ} \mathrm{C}$ for $30 \mathrm{~s}$, and $72^{\circ} \mathrm{C}$ for $90 \mathrm{~s}$, and finally $72^{\circ} \mathrm{C}$ for $480 \mathrm{~s}$. H3 was amplified using the primer pair H3F (5'- ATG GCT CGT ACC AAG CAG ACV GC -3') and H3R (5'- ATA TCC TTR GGC ATR ATR GTG AC -3') [41] with a reaction profile of $95^{\circ} \mathrm{C}$ for $180 \mathrm{~s}, 38$ cycles of $95^{\circ} \mathrm{C}$ for $30 \mathrm{~s}, 53^{\circ} \mathrm{C}$ for $45 \mathrm{~s}$, and $72^{\circ} \mathrm{C}$ for $45 \mathrm{~s}$, and finally $72^{\circ} \mathrm{C}$ for $300 \mathrm{~s}$. COI was amplified using the primer pair LCO1490 (5'-GGT CAA CAA ATC ATA AAG ATA TTG G-3') and HCO2198 (5'ACT TCA GGG TGA CCA AAA AAT CA-3') (700 bp) [42]. The reaction profile was $95^{\circ} \mathrm{C}$ for $180 \mathrm{~s}, 5$ cycles of $95^{\circ} \mathrm{C}$ for $40 \mathrm{~s}, 45^{\circ} \mathrm{C}$ for $40 \mathrm{~s}$, and $72^{\circ} \mathrm{C}$ for $50 \mathrm{~s}, 40$ cycles of $95^{\circ} \mathrm{C}$ for $40 \mathrm{~s}, 51^{\circ} \mathrm{C}$ for $40 \mathrm{~s}$, and $72^{\circ} \mathrm{C}$ for $50 \mathrm{~s}$, and finally $72^{\circ} \mathrm{C}$ for 300 s. $16 \mathrm{~S}$ rRNA was amplified using the primer pair ar (5'-CGC CTG TTT ATC AAA AAC AT-3') and br (5'-CCG GTC TGA ACT CAG ATC ACG T-3') [43] using a reaction profile of $95^{\circ} \mathrm{C}$ for $180 \mathrm{~s}, 35$ cycles of $95^{\circ} \mathrm{C}$ for $40 \mathrm{~s}, 50^{\circ} \mathrm{C}$ for $40 \mathrm{~s}$, and $68^{\circ} \mathrm{C}$ for $50 \mathrm{~s}$, and finally $68^{\circ} \mathrm{C}$ for 300 s. PCR products were purified with ExoSAP-IT (GE Healthcare, Uppsala, Sweden), and sequenced by Retrogen Inc. using Applied Biosystems (ABI) 3730xl DNA analyzers. Overlapping sequence fragments were assembled using Geneious version 5.5 .7 created by Biomatters (available from http://www.geneious.com).

\section{Alignment and assessment of saturation}

Sequences of each gene were aligned using the L-INS-i method of MAFFT 7.110 (Multiple Alignment using Fast Fourier Transform) [44]. The 16S, 18S, and H3 partitions for myzostomids and $16 \mathrm{~S}, 18 \mathrm{~S}$, and $28 \mathrm{~S}$ partitions for crinoids were assessed for ambiguous areas of alignment using the GBlocks server, and questionable areas of alignment were removed using the least stringent settings [45,46]. Substitution saturation was tested for the protein-coding genes (COI and CytB) using DAMBE 5.0.80 [47-49]. When third codon positions were assessed independently assuming a symmetric topology, the third positions of both COI datasets and CytB were found to be substantially saturated or non-informative for phylogenetics (i.e., Iss $>$ Iss.c or Iss $<$ Iss. c p > 0.002). Following this assessment, datasets were concatenated for myzostomids and crinoids to include (where applicable) COI and CytB with third codon removed, and, 16S, 18S, 28S, and $\mathrm{H} 3$ with ambiguous areas of the alignment excluded, as determined by GBlocks. To serve as a comparison, a full dataset was concatenated which includes all data. Alignments for each individual gene partition and the two final concatenated datasets are available at TreeBase (www.treebase.org).

\section{Rooting}

The previous major study by Lanterbecq et al. [18] included a range of terminals in their alignments to serve as a root for Myzostomida. These included members of Rotifera, Platyhelminthes and Annelida. Recent studies (e.g., [10,11]) have confirmed previous views that Myzostomida are in fact members of Annelida [14]. We used here a selection of terminals from Phyllodocida, which morphological data strongly suggests contains the closest relatives of Myzostomida [14], as well as a representative of Amphinomida (Additional file 1: Table S3; Additional file 1: Figures S1 and S3), as the terminals to root the analyses, with the amphinomid Chloeia flava as the actual root.

With respect to the phylogenetic analyses of the echinoderm hosts, we used an asteroid and an ophiuroid in addition to those that were hosts for myzostomids, as these had a full complement of genes available (Additional file 1: Table S3). These were then pruned out of the trees for the co-phylogenetic analysis

\section{Phylogenetic analyses}

Molecular data from a total of 75 myzostomid terminals were included in the phylogenetic analyses (Additional file 1: Table S1). Host identities for 69 of these terminals were known, and these terminals and their hosts were used in tree-estimations for the co-phylogenetic analyses.

Maximum parsimony (MP) analyses were conducted using PAUP*4.0b10 [50] with the heuristic search option for 1000 replicates using random stepwise addition of the terminals with the tree bisection reconnection 
permutation algorithm (TBR). Clade support was determined using 1000 jackknife replicates with 10 random additions per iteration [51].

jModeltest2 was used to determine the most suitable model of molecular evolution for each gene partition under the Akaike Information Criterion (AIC) [52,53]. This resulted in the choice of GTR + I + G for all partitions. Maximum likelihood (ML) analyses were carried out using RAxML (7.4.2) [54] with the RAxML GUI v. 0.93 [55] under the GTR + G and GTR + I + G models of substitution. The data were partitioned by gene and, for protein coding genes, by codon position. This resulted in six partitions for myzostomids and nine partitions for hosts. A thorough bootstrap analysis was carried out with 1000 pseudoreplicates using the same model for the full analysis and for individual gene analyses. Bayesian inference was conducted for each dataset using Mr.Bayes 3.2.2 [56], with two independent Metropolis coupled analyses (runs), each using four Markov chains of 50 million generations. Model choice for each partition was based on the jModeltest 2 results. Run convergence was analyzed using Tracer v1.5 [57]; the first 10 million generations $(10,000)$ trees were discarded as burn-in. The two runs for each dataset of 40,000 trees each $(80,000$ total) were used to generate a majority rule tree with posterior probabilities.

\section{Transformations}

We mapped seven traits relating to life history, geography, and host specificity onto the topology of the maximum likelihood tree (Figure 2), which was mainly congruent with the Bayesian topologies. Character transformations using an Mk1 likelihood model [58] and most parsimonious reconstructions were carried out using Mesquite 2.74 [59]. Unordered, multi-state characters were used for all transformations.

Lifestyle. Five myzostomid lifestyles can be readily distinguished. Most described myzostomids initially develop in a cyst and are free-living on the host as adults (Figure 1A, B, $\mathrm{H}, \mathrm{K})$. Only 28 described species are not free-living as adults - 17 live in permanent galls or cysts on crinoids (Figure 1I, $\mathrm{J}, \mathrm{L}$ ), three reside in the mouth or digestive caeca of crinoids (Figure 1C, F, D), four penetrate the integument or digestive caeca of asteroids via their pharynx (Figure 1E), and four are found within the gonads or bursae of brittlestars (Figure 1G). Among these lifestyles, myzostomids presumably steal the host's food or eat the host directly. Although all forms could be called parasites, we consider separately those stealing food from those eating the host directly; the latter we call 'parasitic host-eaters.' Lanterbecq et al. [18] interpreted some free-living taxa as commensals and an assortment of taxa as parasites (e.g., internal and external host-eaters, galls and cysts food-stealers, and some stationary free-living forms). Terminals were coded:
1. lifestyle, location on host: (0) adult in galls (hard); (1) adult in cysts (soft); (2) adult in mouth or digestive tube; (3) adult a parasitic host-eater; (4) juvenile in cyst before living externally on host.

2. food, source: (0) host's food; (1) host itself.

Host use. Myzostomids are described from three echinoderm classes - asteroids, ophiuroids, and crinoids. Among crinoids, myzostomids are recorded to infect seven major clades (roughly corresponding to taxonomic families), of which four are feather stars (all represented here) and three are stalked crinoids (Bathycrinidae not represented here). Terminals were coded:

1. host, general type: (0) stalked crinoid; (1) feather star crinoid; (2) asteroid; (3) ophiuroid.

2. host, major clade: (0) Isocrinidae; (1) Hyocrinidae; (2) Ptilometridae; (3) Antedonidae; (4)

Tropiometridae; (5) Mariametroidea; (6) Comatulidae; (7) Zenometridae; (7) Asteroidea; (8) Ophiuroidea.

3. specificity, number of hosts: (0) one; (1) two; (2) three.

\section{Comparison of myzostomid and host phylogenies}

A tanglegram of associations among terminals of the myzostomid and host phylogenies was assembled using TreeMap3.0b [60] (Figure 5). Ninety associations were mapped for 69 myzostomid terminals and 53 host terminals. To evaluate possible congruence between the myzostomid and host phylogenies, we used global and event-based methods that could account for multiple associations among hosts and myzostomids. We first ran ParaFit analyses [61] on the phylogenies obtained from maximum likelihood analyses through the program CopyCat [62]. ParaFit does not require fully resolved topologies, and patristic distances were estimated from the branch lengths of the likelihood trees. 9999 replicates were conducted for statistical testing of congruence for the entire structure and individual associations. The null hypothesis tested in this method is random association of host and myzostomids. For an event-based reconciliation analysis, we used JANE [63]. In light of computational limits when working with such a large number of host and myzostomid terminals, we ran analyses only under the default cost settings. We used a generation and population size of 100 in solving the given trees, and a generation and population size of 50 in statistical estimates with random tip mapping and randomizing the parasite tree. In recognition that current methods available to explore tanglegrams were constructed for simpler host-parasite systems, we sought to use co-phylogenetic methods to investigate our data and recognize that the low support in some 
areas of the trees and undersampling of hosts and myzostomids has unexplored effects on the results.

\section{Endnote}

Several taxonomic names (specific epithets) are used here that are not valid for nomenclatural purposes according to ICZN article 8.3 and are not made available through this publication. These will be formally introduced elsewhere (Summers and Rouse in press). These are indicated in the text by: 1. not being in italics, and, 2. being followed by the term 'nomen nudem'.

\section{Additional file}

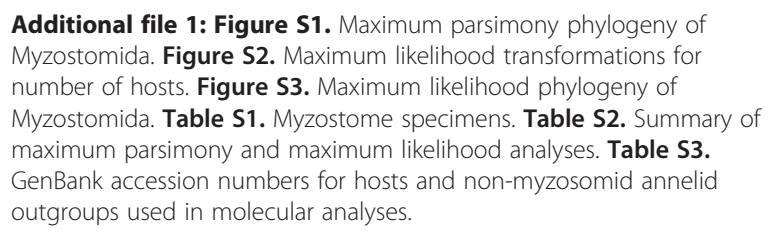

\section{Competing interests}

The authors declare that they have no competing interests.

\section{Authors' contributions}

Both authors contributed to the design, analysis, interpretation of results, and writing. They have read and approve of this manuscript.

\section{Acknowledgements}

We thank Charles Messing (Nova Southeastern University) and Nerida Wilson (Western Australian Museum) for help collecting additional specimens used in this study. Thanks also to C. Messing for suggesting the amusing name Eenymeenymyzostoma. We thank the captains and crews of the R/N Atlantis, RN Western Flyer, RN Melville, and RN Nathaniel B. Palmer and the pilots and crews of the HOV Alvin and ROVs Tiburon, Jason II, and Doc Ricketts for their technical support. Thanks to Harim Cha (Scripps Institution of Oceanography) who kindly accessioned the specimens. We are grateful to Lisa Levin, chief scientist of cruises to Costa Rica and Oregon (2009; 2010, 2011), and Nerida Wilson, chief scientist of cruises to Antarctica (2011, 2103). Bob Vrijenhoek (Monterey Bay Aquarium and Research Institute) kindly invited GWR on the cruises to Monterey Bay and the Guaymas Basin. We thank Anne Hoggett and Lyle Vail, Directors of the Lizard Island Research Station (Great Barrier Reef, Australia), for their assistance; crinoids from Lizard Island were collected under Great Barrier Reef Marine Park Authority permits to GWR (G00/016 and G01/566). Thanks to Philippe Bouchet (Muséum national d'Histoire naturelle, Paris), who invited MMS and GWR to be part of the "Papua New Guinea Revisited" expedition in Madang, Papua New Guinea, and to James Thomas (Nova Southeastern University) and the Christensen Foundation for additional support and funding to join this trip. Max Ammer kindly hosted us in Indonesia at the Raja Ampat Research and Conservation Center, and Inayat Al-Hakim provided essential logistical support and field assistance. Thanks also to Tertius Kammeyer, C. Messing, Allison Miller and Kristian Taylor for field assistance in Indonesia. Indonesian samples were collected under permit to GWR. We thank Marina Mattson and Chia Ming, Yu for their assistance in sequencing the Papua New Guinea myzostomids, and Jose Ignacio Carvajal ensured the molecular work ran smoothly. Charles Messing and Tim O'Hara identified the stalked crinoids and ophiuroids, for which we are grateful. Kristian Taylor kindly allowed us use of COl sequences for two of the Mariametroidea hosts. Nick Holland provided valuable feedback on the manuscript, for which we thank him. This research was funded by the Australian Research Council (A10009136), the US National Science Foundation Graduate Research Fellowship to MMS, and the NSF grants DEB-1036368 (to GWR), NSF ANT 1043749 (to Nerida Wilson, GWR and Ron Burton), and NSF DBI-0706856 (to Lisa Levin and GWR). Other fieldwork costs were also supported by the Australian Museum Foundation (for the
Australian Museum Expedition to Timor-Leste 2012, to GWR), the University of California Friends of the International Center (Madang, MMS) and Scripps Institution of Oceanography (Belize, to GWR).

Received: 4 April 2014 Accepted: 22 July 2014

Published: 28 August 2014

\section{References}

1. Bo M, Rouse GW, Martin D, Bavestrello G: A myzostomid endoparasitic in black corals. Coral Reefs 2013, 33:273-273.

2. Goenaga C: Two new species of Stichopathes (Zoantharia; Antipatharia) with observations on aspects of their biology. In MS thesis. Puerto Rico: University of Puerto Rico; 1977.

3. Okada Y: One species of Myzostomida attached to a hexactinellid sponge. Dobutsugaku Zasshi [Zoological Magazine Tokyo] 1920, 32:324-325.

4. Eeckhaut I, Lanterbecq D: Myzostomida: a review of the phylogeny and ultrastructure. Hydrobiologia 2005, 535/536:253-275.

5. Rouse GW: Encounter 2002 expedition to the Isles of St Francis, South Australia: Myzostoma australe (Myzostomida), a new crinoid associated worm from South Australia. T Roy Soc South Aust 2003, 127:265-268.

6. Grygier MJ: Class Myzostomida. In Polychaetes and allies: the southern synthesis. Fauna of Australia. Volume 4A. Edited by Beesley P, Ross GJB, Glasby CJ. Melbourne: CSIRO Publishing; 2000:297-329.

7. Fishelson L: Ecology of the northern Red Sea crinoids and their epi-and endozoic fauna. Mar Biol 1974, 26:183-192.

8. Potts FA: The fauna associated with the crinoids of a tropical coral reef: with especial reference to its colour variations. Pap Tortugas Lab Carnegie Inst Wash 1915, 8:71-96.

9. Rouse GW: Myzostomida von Graff, 1877. In Polychaetes. Edited by Rouse GW, Pleijel F. Oxford: Oxford University Press; 2001:124-126.

10. Bleidorn C, Eeckhaut I, Podsiadlowski L, Schult N, McHugh D, Halanych KM Milinkovitch MC, Tiedemann R: Mitochondrial genome and nuclear sequence data support Myzostomida as part of the annelid radiation. Mol Biol Evol 2007, 24:1690-1701.

11. Bleidorn C, Lanterbecq D, Eeckhaut I, Tiedemann R: A PCR survey of Hox genes in the myzostomid Myzostoma cirriferum. Dev Genes Evol 2009, 219:211-216.

12. Hartmann S, Helm C, Nickel B, Meyer M, Struck TH, Tiedemann R, Selbig J, Bleidorn C: Exploiting gene families for phylogenomic analysis of myzostomid transcriptome data. PLoS One 2012, 7:e29843.

13. Helm C, Weigert A, Mayer G, Bleidorn C: Myoanatomy of Myzostoma cirriferum (Annelida, Myzostomida): Implications for the evolution of the myzostomid body plan. J Morphol 2012, 274:456-466.

14. Rouse GW, Fauchald K: Cladistics and polychaetes. Zool Scripta 1997 26:139-204.

15. Struck TH, Paul C, Hill N, Hartmann S, Hösel C, Kube M, Lieb B, Meyer A, Tiedemann R, Purschke G, Bleidorn C: Phylogenomic analyses unravel annelid evolution. Nature 2012, 470:95-98.

16. Zrzavý J, Říha P, Piálek L, Janouškovec J: Phylogeny of Annelida (Lophotrochozoa): total-evidence analysis of morphology and six genes. BMC Evol Biol 2009, 9:189.

17. Jägersten G: Zur Kenntnis Der Morphologie, Entwicklung Und Taxonomie Der Myzostomida, Volume 11. Uppsala: Almqvist \& Wiksells Boktryckeri; 1940.

18. Lanterbecq D, Rouse GW, Milinkovitch MC, Eeckhaut I: Molecular phylogenetic analyses indicate multiple independent emergences of parasitism in Myzostomida (Protostomia). Syst Biol 2006, 55:208-227

19. Lanterbecq D, Rouse GW, Eeckhaut I: Bodyplan diversification in crinoid-associated myzostomes (Myzostomida, Protostomia). Invertebr Biol 2009, 128:283-301.

20. Hess $\mathrm{H}$ : Myzostome deformation on arms of the early Jurassic crinoid Balanocrinus gracilis (Charlesworth). J Paleontol 2010, 84:1031-1034

21. Brett CE: Host-specific pit-forming epizoans on Silurian crinoids. Lethaia 1978, 11:217-232

22. Lanterbecq D, Rouse GW, Eeckhaut I: Evidence for cospeciation events in the host-symbiont system involving crinoids (Echinodermata) and their obligate associates, the myzostomids (Myzostomida, Annelida). Mol Phylogenet Evol 2010, 54:357-371. 
23. Eeckhaut I, Jangoux M: Contramyzostoma bialatum (Annelida: Myzostomida), a new genus and species of parasitic myzostome infesting comatulid crinoids. Raffles B Zool 1995, 43:343-354

24. Eeckhaut I, Grygier MJ, Deheyn D: Myzostomes from Papua New Guinea, with related Indo-West Pacific distribution records and description of five new species. B Mar Sci 1998, 62:841-886.

25. Fedotov D: Protomyzostomum polynephris, eine neue Myzostomidenart. Zool Anz 1912, 39:649-653.

26. Fedotov D: Die anatomie von Protomyzostomum polynephris Fedotov. Z für Wissenschaftliche Zoologie 1914, 109:631-696.

27. Eeckhaut I, Jangoux M: Life cycle and mode of infestation of Myzostoma cirriferum (Annelida): a symbiotic myzostomid of the comatulid crinoid Antedon bifida (Echinodermata). Dis Aquat Organ 1993, 15:207-217

28. Rouse GW, Grygier MJ: Myzostoma seymourcollegiorum n. sp. (Myzostomida) from southern Australia, with a description of its larval development. Zootaxa 2005, 1010:53-64.

29. Messing CG: Comatulid crinoids (Echinodermata) of Madang, Papua New Guinea, and environs: diversity and ecology. In Echinoderms through time. Edited by David B, Guille A, Feral JP, Roux M. Rotterdam, Netherlands: Balkema; 1994:237-243.

30. Blanche R: Life in a Gall: the Biology and Ecology of Insects That Live in Plant Galls. Collingwood, Victoria: CSIRO Publishing; 2012

31. Als TD, Vila R, Kandul NP, Nash DR, Yen S-H, Hsu Y-F, Mignault AA, Boomsma JJ, Pierce NE: The evolution of alternative parasitic life histories in large blue butterflies. Nature 2004, 432:386-390.

32. Lyon BE, Eadie JM: An obligate brood parasite trapped in the intraspecific arms race of its hosts. Nature 2004, 432:390-393.

33. Desdevises $Y$, Morand S, Legendre P: Evolution and determinants of host specificity in the genus Lamellodiscus (Monogenea). Biol J Linn Soc 2002, 77:431-443.

34. Poulin R: Evolutionary ecology of parasites. Princeton: Princeton University Press; 2007:332.

35. Althoff DM, Segraves KA, Johnson MTJ: Testing for coevolutionary diversification: linking pattern with process. Trends Ecol Evol 2014, 29:82-89.

36. de Vienne DM, Refrégier G, López-Villavicencio M, Tellier A, Hood ME, Giraud T: Cospeciation vs host-shift speciation: methods for testing, evidence from natural associations and relation to coevolution. New Phytol 2013, 198:347-385.

37. Dawson MN, Raskoff KA, Jacobs DK: Field preservation of marine invertebrate tissue for DNA analyses. Mol Mar Biol Biotech 1998, 7:145-152.

38. Giribet G, Sørensen MV, Funch P, Kristensen RM, Sterrer W: Investigations into the phylogenetic position of Micrognathozoa using four molecular loci. Cladistics 2004, 20:1-13.

39. Rouse GW, Jermiin LS, Wilson NG, Eeckhaut I, Lanterbecq D, Oji T, Young CM, Browning T, Cisternas P, Helgen LE, Stuckey M, Messing CG: Fixed, free, and fixed: the fickle phylogeny of extant Crinoidea (Echinodermata) and their Permian-Triassic origin. Mol Phylogenet Evol 2013, 66:161-181.

40. Giribet G, Carranza S, Baguñà J, Riutort M, Ribera C: First molecular evidence for the existence of a Tardigrada + Arthropoda clade. Mol Biol Evol 1996, 13:76-84.

41. Colgan DJ, McLauchlan A, Wilson GDF, Livingston SP, Edgecombe GD, Macaranas J, Cassis G, Gray MR: Histone H3 and U2 snRNA DNA sequences and arthropod molecular evolution. Aust J Zool 1998, 46:419-437.

42. Folmer O, Black M, Hoeh W, Lutz R, Vrijenhoek R: DNA primers for amplification of mitochondrial cytochrome c oxidase subunit I from diverse metazoan invertebrates. Mol Marine Biol Biotech 1994, 3:294-299.

43. Palumbi SR, Martin AP, Romano SL, McMillan WO: The simple fool's quide to PCR. Honolulu: Dept. of Zoology, University of Hawaii; 1991.

44. Katoh K, Misawa K, Kuma K-I, Miyata T: MAFFT: a novel method for rapid multiple sequence alignment based on fast Fourier transform. Nucleic Acids Res 2002, 30:3059-3066.

45. Castresana J: Selection of conserved blocks from multiple alignments for their use in phylogenetic analysis. Mol Biology Evol 2000, 17:540-552.

46. Talavera G, Castresana J: Improvement of phylogenies after removing divergent and ambiguously aligned blocks from protein sequence alignments. Syst Biol 2007, 56:564-577.

47. Xia X, Xie Z: DAMBE: software package for data analysis in molecular biology and evolution. $J$ Hered 2001, 92:371-373.

48. Xia X, Xie Z, Salemi M, Chen L, Wang Y: An index of substitution saturation and its application. Mol Phylogenet Evol 2003, 26:1-7.
49. Xia X: Phylogenetic relationship among horseshoe crab species: effect of substitution models on phylogenetic analyses. Syst Biol 2000, 49:87-100.

50. Swofford D, Sullivan J: Phylogeny inference based on parsimony and other methods using PAUP*. In The phylogenetic handbook: a practical approach to DNA and protein phylogeny. Boston: Cambridge University Press; 2003:160-206.

51. Farris JS, Albert VA, Källersjo M, Lipscomb D, Kluge AG: Parsimony jackknifing outperforms neighbor-joining. Cladistics 1996, 12:99-124.

52. Darriba D, Taboada GL, Doallo R, Posada D: jModelTest 2: more models, new heuristics and parallel computing. Nat Methods 2012, 9:772.

53. Guindon S, Gascuel O: A simple, fast and accurate method to estimate large phylogenies by maximum-likelihood. Syst Biol 2003, 52:696-704.

54. Stamatakis A: RAxML-VI-HPC: maximum likelihood-based phylogenetic analyses with thousands of taxa and mixed models. Bioinformatics 2006, 22:2688-2690

55. Silvestro D, Michalak I: raxmIGUI: a graphical front-end for RAxML. Org Divers Evol 2012, 12:335-337.

56. Huelsenbeck J, Ronquist F: MrBayes: a program for the Bayesian inference of phylogeny. Bioinformatics 2001, 17:745-755

57. Rambaut A, Suchard MA, Xie D, Drummond AJ: Tracer v1.6. 2007, Available from http://beast.bio.edu.ac.uk/Tracer.

58. Lewis PO: A likelihood approach to estimating phylogeny from discrete morphological character data. Syst Biol 2001, 50:913-925.

59. Maddison WP, Maddison DR: Mesquite: a modular system for evolutionary analysis, version 2.74. [http://mesquiteproject.org] 2010.

60. Charleston MA, Robertson DL: Preferential host switching by primate lentiviruses can account for phylogenetic similarity with the primate phylogeny. Syst Biol 2002, 51:528-535

61. Legendre P, Desdevises Y, Bazin E: A statistical test for host-parasite coevolution. Syst Biol 2002, 51:217-234.

62. Meier-Kolthoff JP, Auch AF, Huson DH, Goker M: COPYCAT : cophylogenetic analysis tool. Bioinformatics 2007, 23:898-900.

63. Conow C, Fielder D, Ovadia Y, Libeskind-Hadas R: Jane: a new tool for the cophylogeny reconstruction problem. Algorithm Mol Biol 2010, 5:16.

\section{doi:10.1186/s12862-014-0170-7}

Cite this article as: Summers and Rouse: Phylogeny of Myzostomida (Annelida) and their relationships with echinoderm hosts. BMC Evolutionary Biology 2014 14:170.

\section{Submit your next manuscript to BioMed Central and take full advantage of:}

- Convenient online submission

- Thorough peer review

- No space constraints or color figure charges

- Immediate publication on acceptance

- Inclusion in PubMed, CAS, Scopus and Google Scholar

- Research which is freely available for redistribution

Submit your manuscript at www.biomedcentral.com/submit
C BioMed Central 